\title{
The occurrence of ovarian cancer in the population of urban and rural women, BRCA1 and BRCA2 genes mutation testing and the general rules on the patient's consent to treatment
}

Występowanie raka jajnika w populacji kobiet miast i wsi, badania mutacji genów BRCA1 i BRCA2 oraz ogólne zasady zgody pacjenta na leczenie

\section{Maria Połocka-Molińska1 ${ }^{\oplus}$, Katarzyna Plagens-Rotman¹ ${ }^{\oplus}$, Wojciech Trusz² ${ }^{\oplus}$, Matylda Gwoździcka-Piotrowska' ${ }^{\oplus}$, Grażyna Jarząbek-Bielecka ${ }^{3}$, Anna Molińska-Kulesza ${ }^{4}$, Witold Kędzia ${ }^{3}$ (อ}

${ }^{1}$ Hipolit Cegielski State University of Applied Sciences/Państwowa Wyższa Szkoła Zawodowa im. Hipolita Cegielskiego ${ }^{2}$ MEDIX in Zielona Góra/MEDIX Zielona Góra ${ }^{3}$ Division of Developmental Gynecology and Sexology, Department of Perinatology and Gynecology, Poznan University of Medical Sciences, Poland/ Pracownia Ginekologii Wieku Rozwojowego i Seksuologii Kliniki Ginekologii Katedry Perinatologii i Ginekologii UMP ${ }^{4}$ Private Medical Practice, New Hospital in Wschowa/Prywatna Praktyka Lekarska, Nowy Szpital Wschowa

CORRESPONDING AUTHOR: Katarzyna Plagens-Rotman Państwowa Wyższa Szkoła Zawodowa im. Hipolita Cegielskiego Stefana Wyszyńskiego 38, 62-200 Gniezno e-mail: plagens.rotman@gmail.com

\section{ORAZ OGÓLNE ZASADY ZGODY PACJENTA NA LECZENI:}

Wprowadzenie. Geny BRCA1 i BRCA2 należą do genów supresorowych, które kontrolują mechanizmy naprawy różnych uszkodzeń podwójnej helisy DNA, regulują podział komórek i cykl komórkowy. Mutacje w obrębie tych genów są związane z dziedzicznym rakiem jajnika i piersi.

Cel pracy. 0cena częstości testowania mutacji genów BRCA1 i BRCA2 w populacji kobiet mieszkających w środowisku miejskim i wiejskim z rozpoznanym rakiem jajnika.

Materiał i metody. Badanie zostało przeprowadzone wśród 300 kobiet zgłaszających się do leczenia lub konsultacji lekarskiej z Wielkopolskiego Centrum Onkologii w Poznaniu oraz pacjentek leczonych w szpitalu domowym powiatu rawickiego w województwie wielkopolskim w latach 2016-2018.

Wyniki. Wśród badanych najwięcej było kobiet w wieku od 36 do 40 lat (53,3\%). Wiek, w którym zachoruje się na raka jajnika u kobiet z miast wynosi od 41 do 45 lat. U zdecydowanej większości kobiet, bo 247 (82,3\%), rozpoznano raka nabłonkowego. Marker mogący wskazywać na raka jajnika, czyli antygen CA 125, stwierdzono u ponad połowy z 165 (55,0\%). Tylko w nielicznych przypadkach, łącznie u 25 (8,3\%) chorych, wykonano test potwierdzający obecność mutacji genów BRCA1 i BRCA2.

Wnioski. Należy rozważyć możliwość wykonania badań pod kątem mutacji genów BRCA1 i BRCA2 u wszystkich chorych kobiet i ich najbliższej rodziny. Niezależnie od wieku kobiet ważne jest, aby zwiększać świadomość ryzyka raka jajnika zachęcając ich do regularnych wizyt lekarskich i wykonywania badań diagnostycznych.

Słowa kluczowe: rak jajnika, mutacje genu BRCA, profilaktyka

\footnotetext{
THE OCCURRENCE OF OVARIAN CANCER IN THE POPULATION OF URBAN AND RURAL WOMEN, BRCA1 AND BRCA2 GENES MUTATION TESTING AND THE GENERAL RULES ON THE PATIENT'S CONSENT TO TREATMENT

Introduction. The BRCA1 and BRCA2 genes belong to suppressor genes that control the mechanisms of repairing various damages of the DNA double helix, regulate cell division, and the cell cycle. Mutations within these genes are associated with the hereditary ovarian and breast cancers.

Aim. Assessment of the frequency of testing BRCA1 and BRCA2 gene mutation in the population of women living in urban and rural environments with diagnosed ovarian cancer.

Material and methods. The study was conducted among 300 women seeking treatment or consulting a doctor from the Wielkopolska Oncology Center in Poznań, and patients treated in a home hospice in the Rawicz district in Wielkopolska province over the period 2016-2018.
} 
Results. Among the respondents, the most were women aged from 36 to 40 (53.3\%). The age of developing ovarian cancer for the women from cities is between 41 and 45. In the vast majority of women, i.e. 247 (82.3\%), epithelial cancer was diagnosed. A marker that could indicate ovarian cancer, i.e. CA 125 antigen, was determined in more than half of 165 (55.0\%). However, only in a few cases, in a total of 25 (8.3\%) patients a test confirming the presence of BRCA1 and BRCA2 gene mutation was performed.

Conclusions. The possibility of testing for BRCA1 and BRCA2 gene mutation in all sick women and their closest family should be considered. Regardless of the age of women, it is important to raise awareness of the risk of ovarian cancer, encourage them to keep regular medical appointments, and perform diagnostic tests.

Key words: $\quad$ ovarian cancer, BRCA gene mutations, prophylaxis

\section{INTRODUCTION}

Ovarian cancer is one of the most malignant and relatively late-detectable tumours of female genitals. It causes changes in the metabolism of the epithelial cells that cover the ovary; as a result, they begin to behave incorrectly. Instead of undergoing apoptosis, which means programmed form of death, cells are constantly multiplying, which leads to cancerous growth. Initially, a primary focus of the neoplastic process forms an organ, and then through further uncontrolled growth, the destruction of neighbouring tissues occurs.

In 2017, 3775 cases of ovarian cancer were diagnosed in Poland, which accounts for $4.6 \%$ of women with malignant neoplasms ( 82425 cases). This is the fourth most common (after lung, breast, and colon cancer) cause of cancer deaths among women [1]. Each year, approximately 3,000 Polish women are diagnosed with ovarian cancer, the second most common cause of death among perimenopausal women.

Despite the huge recent advances in medicine, diagnostics and introduction of ever newer generations of anti-cancer drugs, the results of the treatment are unfortunately unsatisfactory. The fact that in about $75 \%$ cases ovarian cancer is diagnosed in III and IV advancement stage is still a very big problem $[2,3,4]$. At an earlier stage, the diagnosis of ovarian cancer is coincidental because the clinical signs of ovarian cancer are uncharacteristic and often ignored.

Unlike in most cancers, there is no typical screening in ovarian cancer. It is known that BRCA1 and BRCA2 gene mutations carrier is a factor that increases the risk of developing not only ovarian and breast cancer, but also pancreatic cancer, melanoma, and prostate cancer in men. Women who are carriers of the BRCA 1 mutation are at $59 \%$ risk of developing ovarian cancer, and those with BRCA 2 mutation $16.5 \%$ [5]. Therefore, testing for the presence of mutations in these genes should be one of the basic methods assessing the risk of developing this disease in our country.

Genetic testing is especially important for women diagnosed with cancer, but also as a test to determine the risk of family disease. The best solution would be to test every woman with a family history of ovarian or breast cancer for a BRCA1 and BRCA2 mutation carrier [6].

\section{AIM}

The aim of the study was to evaluate the frequency of performing BRCA1 and BRCA2 gene mutation tests in the population of women living in urban and rural environments with diagnosed ovarian cancer.

\section{MATERIALS AND METHODS}

The selection of respondents was targeted because only women who were diagnosed with ovarian cancer, identified by histopathological examination, were qualified to complete the survey. The study was conducted among 300 women in the age range from 30 to 45 years. The average age was 39.1 years. Participation in the study was voluntary and anonymous. A diagnostic survey was adopted as a research method and a tool used to collect the necessary data was a survey questionnaire constructed for the purposes of this study. Information confirming or contradicting the BRCA gene mutation test was obtained directly from the respondents.

The questionnaire was filled in by women seeking medical treatment or medical advice in Wielkopolska Cancer Center in Poznan and patients treated in a home hospice in the Rawicz district in Wielkopolska province over the period 2016-2018.

\section{RESULTS}

After analysing the age of rural and urban female dwellers, it was found that the largest number constituted women aged from 36 to 40 (53.3\%). Secondary education dominated among the rural and urban dwellers. Among the women living in rural environments 63 (42.0\%) had secondary education; $67(44.7 \%)$ among city dwellers. Only 8 (2.7\%) of the respondents had primary education.

As many as $82(54.7 \%)$ of respondents living in the cities declared that the age of their first menarche was 10 years. Among rural women, 69 respondents (46.0\%) had their first menstrual period at the age of 11 . A total of 117 (39.0\%) women gave birth at least once, while almost every third woman did not give birth - 91 (30.4\%).

\begin{tabular}{|c|c|c|c|c|c|c|}
\hline \multirow{2}{*}{$\begin{array}{c}\text { Socio-demographic } \\
\text { factors }\end{array}$} & \multicolumn{2}{|c|}{$\begin{array}{c}\text { Female city } \\
\text { dwellers }\end{array}$} & \multicolumn{2}{|c|}{$\begin{array}{c}\text { Female village } \\
\text { dwellers }\end{array}$} & \multicolumn{2}{|c|}{ In total } \\
\hline & $\mathbf{N}$ & $\%$ & $\mathbf{N}$ & $\%$ & $\mathbf{N}$ & $\%$ \\
\hline \multicolumn{7}{|l|}{ Age ranges: } \\
\hline $30-35$ & 39 & 26.0 & 36 & 24.0 & 75 & 25.0 \\
\hline $36-40$ & 78 & 52.0 & 88 & 58.7 & 166 & 53.3 \\
\hline $41-45$ & 33 & 22.0 & 26 & 17.3 & 59 & 19.7 \\
\hline \multicolumn{7}{|l|}{ Marital status: } \\
\hline Single & 11 & 7.3 & 21 & 14.0 & 32 & 10.7 \\
\hline Married & 101 & 67.4 & 109 & 72.7 & 210 & 70.0 \\
\hline Divorced & 38 & 25.3 & 20 & 13.3 & 58 & 19.3 \\
\hline \multicolumn{7}{|l|}{ Education: } \\
\hline Primary School & 3 & 2.0 & 5 & 3.3 & 8 & 2.7 \\
\hline Basic Vocational School & 38 & 25.3 & 27 & 18.0 & 65 & 21.7 \\
\hline High School & 67 & 44.7 & 63 & 42.0 & 130 & 43.3 \\
\hline University degree & 42 & 28.0 & 55 & 36.7 & 97 & 32.3 \\
\hline In total & 150 & 100.0 & 150 & 100.0 & 300 & 100.0 \\
\hline
\end{tabular}


The age of developing ovarian cancer for the respondents from cities is between 41 and 45 years. This range was marked by $72(48 \%)$ respondents. More than half -81 (54\%) of rural women marked the age between 36 and 40 years. The vast majority of women - a total of $247(82.3 \%)$ were diagnosed with epithelial cancer. More than half 151 (50.3) of respondents did not use oral contraceptives.

The marker that could indicate ovarian cancer, i.e. Antigen CA 125, was determined in more than half of $165(55.0 \%)$, however, only in a few cases, in a total of $25(8.3 \%)$ patients, a test confirming the occurrence of BRCA1 and BRCA2 gene mutations was performed. The above test was performed only in young women with ovarian cancer diagnosed up to 35 years of age. When answering the question about the occurrence of ovarian and breast cancer in their immediate family (mother, sister, grandmother) only 41 (13.7\%) of the respondents gave an affirmative answer. As many as 241 (80.3\%) respondents said that the cancer only occurred in them. Detailed figures and percentages are presented in Table 2.

Tab. 2. Medical data of the respondents

\begin{tabular}{|c|c|c|c|c|c|c|}
\hline \multirow{2}{*}{$\begin{array}{c}\text { Selected } \\
\text { medical data }\end{array}$} & \multicolumn{2}{|c|}{$\begin{array}{l}\text { Female city } \\
\text { dwellers }\end{array}$} & \multicolumn{2}{|c|}{$\begin{array}{c}\text { Female village } \\
\text { dwellers }\end{array}$} & \multicolumn{2}{|c|}{ In total } \\
\hline & $\mathbf{N}$ & $\%$ & $\mathbf{N}$ & $\%$ & $\mathbf{N}$ & $\%$ \\
\hline $\begin{array}{l}\text { Age of first menstrual } \\
\text { period: } \\
10 \text { years }\end{array}$ & 82 & 54.7 & 27 & 18.0 & 109 & 36.3 \\
\hline 11 years & 11 & 7.3 & 69 & 46.0 & 80 & 26.7 \\
\hline 12 years & 15 & 10.0 & 33 & 22.0 & 48 & 16.0 \\
\hline 13 years & 33 & 22.0 & 19 & 12.7 & 52 & 17.3 \\
\hline 14 years & 9 & 6.0 & 2 & 1.3 & 11 & 3.7 \\
\hline Births carried out: & & & & & & \\
\hline One & 56 & 37.3 & 61 & 40.7 & 117 & 39.0 \\
\hline Two & 43 & 28.7 & 27 & 18.0 & 70 & 23.3 \\
\hline Three and more & 13 & 8.7 & 9 & 6.0 & 22 & 7.3 \\
\hline None & 38 & 25.3 & 53 & 35.3 & 91 & 30.4 \\
\hline Age of onset: & & & & & & \\
\hline $30-35$ & 12 & 8.0 & 15 & 10.0 & 27 & 9.0 \\
\hline $36-40$ & 66 & 44.0 & 81 & 54.0 & 147 & 49.0 \\
\hline $41-45$ & 72 & 48.0 & 54 & 36.0 & 126 & 42.0 \\
\hline Cancer Type: & & & & & & \\
\hline Epithelial & 118 & 78.7 & 129 & 86.0 & 247 & 82.3 \\
\hline Embryonic & 13 & 8.7 & 14 & 9.3 & 27 & 9.0 \\
\hline Gonadal & 19 & 12.7 & 7 & 4.7 & 26 & 8.7 \\
\hline Using oral contraception: & & & & & & \\
\hline Yes & 77 & 51.3 & 62 & 41.3 & 139 & 46.3 \\
\hline No & 66 & 44.0 & 85 & 56.7 & 151 & 50.3 \\
\hline For 3 months only & 7 & 4.7 & 3 & 2.0 & 10 & 3.4 \\
\hline Determination of markers: & & & & & & \\
\hline CA125 & 72 & 48.0 & 93 & 62.0 & 165 & 55.0 \\
\hline LDH, HCG, AFP & 69 & 46.0 & 41 & 27.3 & 110 & 36.7 \\
\hline BRCA1/2 gene mutations & 9 & 6.0 & 16 & 10.7 & 25 & 8.3 \\
\hline $\begin{array}{l}\text { Prevalence of cancer } \\
\text { in the immediate family }\end{array}$ & & & & & & \\
\hline Yes & 24 & 16 & 17 & 11.3 & 41 & 13.7 \\
\hline No & 119 & 73.3 & 122 & 81.3 & 241 & 80.3 \\
\hline No knowledge & 7 & 4.7 & 11 & 7.4 & 18 & 6.0 \\
\hline In total & 150 & 100.0 & 150 & 100.0 & 300 & 100.0 \\
\hline
\end{tabular}

\section{DISCUSSION}

Early detection of ovarian cancer is a major challenge for modern medicine.The development of ovarian cancer is more commonly seen in postmenopausal women and those, whose first menstrual period occurred before the age of 12 . The women who were pregnant and gave birth before the age of 26 are at lower risk of developing ovarian cancer compared to non-pregnant women. In addition, this risk decreases with each subsequent pregnancy [7].

What is more, the low number of full-term pregnancies and infertility are also associated with a higher risk of developing ovarian cancer $[8,9,10,11]$. Other risk factors associated with hormonal status include late menopause, long ovulation, spontaneous miscarriages or increased symptoms of premenstrual syndrome. Hormone replacement therapy also increases the risk of ovarian cancer, more in estrogens than estrogens-progesterone therapy. The protective effect of sterilization by ligation of the fallopian tubes with removal of the uterus has also been demonstrated.

This study has been aimed to show what factors affect the risk of ovarian cancer. Most often they are mature women over 45 years, who enter perimenopausal period, and the peak of this disease is observed between 50 and 59. Unfortunately, the research conducted for the purposes of this study differs from the reports of other authors. The results obtained showed that less than half of 147 (49.0\%) of all respondents living in rural and urban environments ( $54 \%$ and $44 \%$ women respectively) are women under 40 years. What is important, $9 \%$ of respondents develop the cancer between 30 and 35 years. Incidence of ovarian cancer in women between the ages of 15 and 29 is estimated at $4 \%$; while under 30 years at $1 \%$ [12].

Increased risk of developing ovarian cancer is observed in women who have no offspring, more precisely, who have never given a birth. Can it be confirmed on this basis that pregnancy and childbirth reduce the risk and thus significantly reduce development of ovarian cancer? Ovulation may have a potentially mutagenic effect because this process requires the rupture of epithelium adjacent to the site of rupture of the Graff follicle resulting in proliferation of epithelial cells from the environment surrounding the wound. During this process inclusion cysts are formed in which epithelial cells are trapped in which carcinogenesis processes may occur.

Analysis of the research shows that despite giving birth to a child, women still develop ovarian cancer. Only 91 out of 300 women (30.4\%) did not become pregnant and had no offspring. Thus, it cannot be unequivocally stated that giving a birth protects against developing ovarian cancer. Analysing the intake of oral contraceptives among the respondents regarding the occurrence of the disease, it has been shown that among all the 300 surveyed women living in villages and cities in less than half - 139 (47.3\%) of cases, taking oral contraception did not protect them from falling ill. Not much more - 151 (50.3\%) patients did not use oral contraceptives.

Summing up the factors increasing or decreasing the risk of ovarian cancer, it can be seen that age, place of residence 
number of deliveries or taking oral contraceptives in no way protect against ovarian cancer.

A broader introduction of genetic testing for BRCA $1 / 2$ should be considered, especially in high-risk groups. This is important to identify people who are at high risk for a family history of cancer, and it may also be important to select individual treatment for ovarian/breast cancer in BRCA $1 / 2$ mutation carriers [13, 14].

The so-called „Founder's effect” in the BRCA 1 gene was found in the Polish population. On its basis a rapid genetic test was developed. The test detects the three most common mutations of the BRCA 1 gene (5382insC, C61G and $4153 \mathrm{delA}$ ). The sensitivity of this test is approximately $85 \%$ and it should be performed as a „screening” test [15].

A separate aspect of the study on population-based BRCA mutation that should be considered is the very interest in performing the test in families at high risk of the disease. A study published in 2020 by Riedlov P. et al. showed that only $9.9 \%$ of high-risk patients (21/212) showed willingness to perform it [16]. This suggests the need for a deeper analysis of the reasons for rare testing in patients from families burdened with the disease and the need for implementing an educational programme that will show the desirability of doing this type of research.

The regularity of gynaecological examinations, ultrasound testing, educating and leading a healthy lifestyle through its modifications, as well as self-observation for any disturbing symptoms will significantly contribute to early detection of the disease and taking appropriate steps to treat cancer of the reproductive organs in women $[16,17,18,19]$.

Patient's autonomy - the question of the decision on the choice of treatment method after comprehensive and universal information by the doctor

In the light of law, a patient is a natural person (both adult and a child) who benefits from health services. As a rule, the patient must agree to the treatment methods proposed by the doctor, including those used to treat the cancer issue.

Pursuant to the provision of art. 16 of the Polish Act of November 6, 2008 on patient rights and the Ombudsman for Patient Rights (hereinafter referred to as UPP) [20], the patient has the right to consent to certain health services or refusal of such consent after obtaining information about the state of his health and possible methods of treatment (art. 9 of UPP - the patient has the right to information about his state of health). This right can be fully exercised only by adults and incapacitated persons. In the case of children and adolescents, i.e. natural persons under 18 years of age, we may speak about the so-called cumulative consent - this situation applies to a person who is at least 16 years old, or lack of the right to make an independent decision or cumulative decision, except for consent to receive tissues for transplantation.

A person under 16 years of age is not entitled to decide (including co-decide) on the method of treatment. Here the decision belongs to the parents or legal guardians. The provision of the art. 9 item 7 UPP, however, gives a minor patient the right to obtain accessible information about the state of health, diagnosis, proposed and possible diagnostic and therapeutic methods, foreseeable consequences of their use or abandonment, results of treatment and prognosis in the scope and form needed for the proper course of the diagnostic or therapeutic process. At the same time, attention should be paid to the provision of art. 15, paragraph 2 of the Code of Medical Ethics, which stipulates that in the case of a minor, a physician should also try to obtain his/her consent, provided that he or she is able to express it consciously [21]. In turn, the lack of consent of the legal representative (parents, legal guardians) precludes action, even if the doctor has obtained the consent of the minor.

\section{CONCLUSIONS}

The material collected throughout the course of the research has allowed to make the following observations:

1. The possibility of testing for BRCA1 and BRCA2 gene mutation in all women with ovarian cancer and their immediate family as well as encouraging them to do the tests should be considered.

2. Regardless of the age of women, it is important to raise awareness of the risk of ovarian cancer and to encourage regular medical appointments as well as diagnostic tests.

3. The patient must agree to the treatment methods proposed by the doctor, including those used to treat the cancer issue (bearing in mind the legal regulation concerning the minor patient).

\section{ORCID}

Maria Połocka-Molińska (iD) https://orcid.org/0000-0002-5479-8228 Katarzyna Plagens-Rotman (iD) https://orcid.org/0000-0001-7646-7430 Wojciech Trusz (iD) https://orcid.org/0000-0002-4056-0331 Matylda Gwoździcka-Piotrowska iD https://orcid.org/0000-0002-1518-3677 Grażyna Jarząbek-Bielecka (iD https://orcid.org/0000-0003-1385-5641 Witold Kędzia (iD https://orcid.org/0000-0001-9905-0857

\section{REFERENCES}

1. Didkowska J, Wojciechowska U, Czaderny K. Nowotwory złośliwe w Polsce w 2017 roku. Krajowy Rejestr Nowotworów. Warszawa: Centrum Onkologii - Instytut im. Marii Skłodowskiej-Curie, 2019.

2. Plagens-Rotman K, Chmaj-Wierzchowska K, Pięta B, Bojar I. Modifiable lifestyle factors and ovarian cancer incidence in women. Ann. Agric. Environ. Med. 2018; 1: 36-40.

3. Kurman RJ, Shih IM. The Origin and Pathogenesis of Epithelial Ovarian Cancer: A Proposed Unifying Theory. Am. J. Surg. Pathol. 2010; 34: 433-443.

4. Budiana ING, Angelina M, Pemayun TGA. Varian cancer: Pathogenesis and current recommendations for prophylactic surgery. J. Turk. Ger. Gynecol. Assoc. 2019; 26: 47-54.

5. Mavaddat N, Peock S, Frost D. Cancer risks for BRCA1 and BRCA2 mutation carriers: results from prospective analysis of embrace. J. Natl. Cancer. Inst. 2013; 5: 812-822.

6. Dowdy SC, Stefanek M, Hartmann LC. Surgical risk reduction: prophylactic salpingooophorectomy and prophylactic mastectomy. Am. J. Obstet. Gynecol. 2004; 191: 1113-1123.

7. Koh SC, Huak CY, Lutan D, et al. Combined panel of serum human tissue kallikreins and CA-125 for the detection of epithelial ovarian cancer. J. Gynecol. Oncol. 2012; 23: 175-181.

8. Kossai M, Leary A, Scoazec J-Y, Genestie C. Ovarian Cancer; A heterogeneous disease. Pathobiology. 2018; 85(1-2): 41-49.

9. Xinxin Z, Jinghe L. Programmed death-1Pathway Blockade Produces a Synergistic Antitumor Effect Combined Application In Ovarian Cancer. J. Gynecol. Oncol. 2017; 5: 64 . 


\section{Maria Połocka-Molińska, Katarzyna Plagens-Rotman, Wojciech Trusz, et al}

10. Eisenhauer EA. Real-world evidence. In the treatment of ovaria cancer. Ann. Oncol. 2011; 1(8): 28.

11. Vargas AN. Natural history of ovarian cancer. J. Cancer. Sci. Ther. 2014; 6: 247-252.

12. Lalrinpuii E, Bhageerathy PS, Sebastian A. Ovarian Cancer in Young Women. Peedicayil. A Indian. J. Surg. Oncol. 2017; 4: 540-547.

13. Pujade-Lauraine E, Ledermann JA, Selle F, et al. Olaparib tablets as maintenance therapy in patients with platinum-sensitive, relapsed ovarian cancer and a BRCA1/2 mutation (SOLO2/ENGOT-0V21): a double-blind, randomised, placebo-controlled, phase 3 trial. Lancet Oncol. 2017; 9: 1274-1284.

14. Kruczała MA, Grela-Wojewoda A, Cedrych I. PARP inhibitors in the ovarian cancer therapy. Ginekol. Pol. 2016; 87: 131-134.

15. Górski B, Byrski T, Huzarski T, et.al. Founder mutations in the BRCA1 gene in Polish families with breast-ovarian cancer. Am. J. Hum. Genet. 2000; 6: 1963-1968.

16. Riedlova $P$, Janoutova J, Hermanova B. Frequency of mutations in BRCA genes and other candidate genes in high-risk probands or probands with breast or ovarian cancer in the Czech Republic. Mol. Biol. Rep. 2020; 4: 2763-2769.

17. Plagens-Rotman K, Chuchracki M, Piskorz-Szymendera M, et al. Reproductive factors and the endometrial cancer morbidity. Eur. J. Gynaecol. Oncol. 2019; 3: 431-436.

18. Plagens-Rotman K, Piskorz-Szymendera M, Chmaj-Wierzchowska K, Pięta B. Breast cancer - Analysis of the selected risk factors. Eur. J. Gynaecol. Oncol. 2017; 3: 425-430.

19. Plagens-Rotman K, Żak E, Pięta B. Odds ratio analysis in women with endometrial cancer. Prz. Menopauz. 2016; 1: 12-19.

20. Act of November 6, 2008 on patient rights and the Ombudsman for Patient Rights (consolidated text of the Journal of Laws of 2020, item 849).

21. the Code of Medical Ethics (https://nil.org.pl/uploaded_images/1574857770_ kodeks-etyki-lekarskiej. pdf, access: 11.06.2020).
Manuscript received: 19.11.2020

Manuscript accepted: 08.12.2020

Translation/Tłumaczenie: Matylda Gwoździcka-Piotrowska 